\section{Voice Disorder: case definition and prevalence in teachers}

\section{Disfonia: definição de caso e prevalência em professores}

Renata Jardim ${ }^{1}$

Sandhi Maria Barreto

Ada Ávila Assunção

${ }^{1}$ Speech Therapist, master in Public Heath

${ }^{2}$ School of Medicine. Universidade Federal de Minas Gerais

Correspondência: Renata Jardim. Rua Castelo de Abrantes, 424/203, Castelo. Cep 31330-020 Belo Horizonte/MG. E-mail: jardimre@hotmail.com.br

\section{Abstract}

Several studies have shown a high prevalence of voice disorders among teachers. However, it is difficult to establish comparisons among the results found given the great variability among criteria and symptoms used to define the presence of vocal alteration, in addition to the variations in the composition of the populations studied (age, gender, origin, working schedule, profession, among others).

This study aims to discuss the need for a standard definition of functional voice disorder and possible implications of the lack of such a standard definition on estimating the prevalence of functional voice disorders among teachers. A systematic bibliographic review on voice disorders in teachers was carried out as of 1990 in the Medline, Scielo, Ovid, Pubmed and Lilacs databases.

Of the 3,186 citations, 15 fulfilled the inclusion criteria to discuss prevalence of vocal disorder in teachers. Nine articles defined vocal disorder based solely on the presence of vocal symptoms, which varied in relation to type, number, frequency, and reference period. Hoarseness and vocal tiredness were mentioned in all studies that evaluated vocal symptoms. Only three studies reported prevalence based on professional examination. Prevalence rates varied according to reference period and frequency of symptoms. The results ratified the importance of standardizing the case definition of voice disorder in order to better study and understand its occurrence and to compare prevalence obtained from different populations and along time in the same population. Standardized definitions should include laryngeal alterations observed in later phases of voice disorder as well as signs and symptoms present in phases previous to organic alterations, when they are potentially reversible.

Keywords: Voice disorder. Teachers. Prevalence. Vocal symptoms and work. 


\section{Resumo}

Várias pesquisas têm mostrado elevada prevalência de disfonia em professores, porém não há uma definição padronizada de alteração vocal nos estudos realizados, o que dificulta a comparação dos resultados obtidos e o desenvolvimento da pesquisa na área.

O objetivo deste estudo foi discutir a necessidade de padronizar a definição de disfonia funcional e discutir possíveis implicações da falta da padronização na estimação da prevalência da disfonia funcional em professores. Foi realizada uma revisão bibliográfica sistemática sobre disfonia em professores, por meio de consulta a diversas bases de dados, sendo considerados os artigos publicados a partir de 1990 .

De 3.186 citações, 15 artigos preencheram os critérios de inclusão para a discussão da prevalência da disfonia em professores. Nove artigos definiram disfonia baseados somente na presença de sintomas vocais, com variações em relação ao tipo, número, freqüência e período de referência. Rouquidão e cansaço vocal foram mencionados em todos os estudos que avaliaram sintomas vocais. Somente três estudos analisaram a prevalência da disfonia baseada na avaliação profissional. As prevalências variaram conforme o período de referência e a freqüência dos sintomas pesquisados.

Os resultados ratificaram a importância de padronizar a definição de disfonia para melhor estudar e compreender a sua ocorrência e comparar a prevalência obtida em diferentes populações e através do tempo, em uma mesma população. A definição padronizada da disfonia deveria incluir alterações laríngeas observadas em fases mais avançadas da disfonia, assim como sinais e sintomas presentes em fases que precedem as alterações orgânicas, potencialmente reversíveis.

Palavras-chave: Disfonia. Professores. Prevalência. Sintomas vocais e trabalho.

\section{Introduction}

The voice is an important work tool. In fact, a job can be classified based on its demand regarding voice quality and vocal load $^{1}$. Actors and singers comprise the group that needs high quality and high vocal load; radio and TV casters have high quality and moderate vocal load; school and kindergarten teachers need moderate quality and high vocal load.

Voice professionals make intensive use of their voice, frequently under environmental and organizational constraints ${ }^{2-6}$. In teachers' work, the voice assumes an outstanding importance, influencing their relationship with students and among their partners. Teachers' voice is an important resource to gain respect, attention and make work more interesting. Voice quality and teachers' way of expression can influence students' receptivity to lessons. Yura et al. $^{7}$ found an association between graphic mistakes in $2^{\text {nd }}$ grade school children and teachers' voice alterations during dictate exercises. Rogerson and Dodd ${ }^{8}$, in a study with 107 children aged 9.8 years on average, came to the conclusion that any degree of vocal alteration (mild or severe) may interfere in children's speaking process and, therefore, may have a negative effect on their education.

Noise, the number of students in the classroom, working schedule, dust, chalk use, classroom lighting and ventilation, years of teaching, difficult relationship with colleagues, students and authorities, among other factors, tend to impose an intense vocal load. According to Vilkman ${ }^{9}$, vocal load is a combination of vocal loading time with additional factors such as size of groups, background noise, unsuitable environmental acoustics, and bad air quality, which end up affecting the fundamental frequency, type and loudness of phonation or the vibratory characteristics of the vocal folds as well as the external frame of the larynx.

A study by Martins et al. ${ }^{4}$ in a primary school in the city of São Paulo, Brazil, mea- 
sured the relation between vocal signal and noise in different hours and places, and considered a suitable level for learning as $>15 \mathrm{~dB}$. They found environmental noise varying from 58 to $84 \mathrm{~dB}(\mathrm{~A})$, reaching $110 \mathrm{~dB}(\mathrm{~A})$ during the school break, while teachers' voice intensity varied from 79.5 to $90.5 \mathrm{~dB}(\mathrm{~A})$, intensities only found in a screaming voice.

Voice disorders in teachers have been the object of several studies given their high prevalence. In a cross sectional study of work and health conditions ${ }^{6}$ of 250 private school teachers in Vitória da Conquista, Brazil, 93\% of teachers reported intensive voice use, $62 \%$ felt tired when speaking and $57 \%$ had to make an effort to be heard. Delcor et al. ${ }^{6}$ studied 573 private school teachers in Salvador, Brazil, and found $23 \%$ of temporary voice loss and $12 \%$ of nodules in vocal folds.

Eighty seven percent of 772 teachers examined by an otolaryngology service in Buenos Aires, Argentina ${ }^{5}$, from 1985 to 1998, had functional voice disorders. The most common symptom was decrease in voice strength, involving intensity (physical aspect), sonority (physical-physiological aspect) and the sensation of a foreign body in the larynx.

The voice may be characterized by its vocal quality according to vocal parameters such as fundamental frequency, intensity, resonance, and vocal intonation. The perceptual correlates of frequency are called pitch or subjective frequency sensation adequate to age and sex and, the perceptual correlate of intensity, are called loudness, or subjective intensity sensation adequate to the environment ${ }^{10}$.

An individual's voice indicates characteristics such as gender, age, personality traits, emotional state and cultural heritage $^{11}$. It expresses individual identity and allows distinguishing one individual from another. In different phases of life - childhood, teenage, adulthood and old age - the voice reflects several aspects of the individual's physical, social, cultural and psychological development ${ }^{12}$.
A healthy voice is the one that fully meets the speaker's professional and/or personal needs and is kept along a person's life without difficulties. Hormonal alterations, allergies, flu, vascular problems, neurological and psycho-emotional disorders, surgeries as well as other factors related to general health may influence vocal health ${ }^{10}$.

However, there are no standardized parameters to evaluate the patterns and limits of a normal voice and some changes in voice are expected and socially acceptable during vocalization. But, even taking these changes into account, some alterations cannot be considered as markers of social or emotional expression. These changes are then regarded as dysphonia ${ }^{11}$.

According to Speech-language pathology, dysphonia is any alteration in the performance or production of the voice that may interfere in communication ${ }^{14}$. In the American Heritage ${ }^{\circledR}$ Stedman's Medical Dictionary, dysphonia is defined as a difficulty in speaking, usually evidenced by hoarseness ${ }^{15}$.

Dysphonia or voice disorder is diagnosed by speech therapists and otorhinolaryngologists, following a clinical evaluation based on subjective and objective factors. They are classified as functional, organic or organic-functional. Functional dysphonia is caused by vocal misuse and occurs in the absence of an organic alteration. Organic dysphonia is not caused, but can be worsened, by vocal behavior. Organicfunctional dysphonia results, in general, from a late diagnosis of functional dysphonia, being, thus, a consequence of voice misuse ${ }^{14,16}$. The incidences of functional and organic-functional disorders are, thus, of greater interest because they can be prevented, in contrast to organic dysphonia.

Voice disorders may be determined or worsened by countless factors external to an individual's behavior. The environment in which the voice is used determines the way in which the voice has to stand out. Speaking a lot in itself may not provoke vocal disorders, but vocal overstraining can 
be a causal factor of work related voice disorders.

The study of any health condition in population groups requires a clear definition of the condition under study, which allows the investigator to differentiate healthy from unhealthy individuals. As pointed out before, the definition of voice disorder is not standardized and assumes different forms and classifications in different studies. It is a complex, multi-determined phenomenon with different ways of expression and, consequently, of diagnosis. As a result, it is difficult to establish comparisons among the results of studies on functional or organic-functional voice disorders, given the great variability in the criteria and symptoms used to define the presence of such alterations.

Because voice disorder results from an underlying alteration in the structures or in the work of the vocal trait: breathing, vocalization or resonance, it may be expressed by several symptoms. The most common include tiredness or effort when speaking, throat clearing or persistent coughing, sensation of tightness or weight in the throat, voice breaks, breathlessness when speaking, aphonia, soreness or burning in the throat, hoarseness ${ }^{17-21}$.

This study aims to discuss the need for a standard definition of functional voice disorder and to discuss possible implications of the lack of such a standard definition on epidemiological studies of the prevalence of these disorders among teachers.

\section{Methods}

A systematic bibliographic review on voice disorders in teachers was carried out in the Medline, Scielo, Ovid, Pubmed and Lilacs databases for the 1990-2005 period. Key-words used in the research were: voice disorder, vocal alterations/problems, teachers, vocal symptoms, voice professionals and vocal health.

All abstracts were read by one of the authors (JR) and the full article was selected only when all the following inclusion criteria were fulfilled:

- The article was published in Portuguese, English, French or Spanish;

- The article presented the results of an observational epidemiological study on prevalence of voice disorder;

- The study population was public or private school teachers at any educational level.

The quality of the study was not considered nor judged. All the articles that met the inclusion criteria were then read and grouped according to characteristics of the study population, definition of voice disorder employed and prevalence of the condition. We also identified if voice alteration was based on a report of a previous diagnosis of the condition by a health professional

In each study, the number of symptoms, signs, frequency and period used to define voice disorders were identified. We also evaluated the consequence of a given case definition by its impact on the prevalence of the disorder in a given period. For instance, a definition based on presence of any vocal symptom with no regard to number, frequency and period would necessarily tend to define as positive almost everyone in the study population, being very little informative. A definition based on presence of two or more vocal symptoms, such as everyday in the last 15 days, would be clearer and easier to interpret and compare.

In order to identify positive and negative aspects of a given definition, we used a proxy to the concept of sensitivity and specificity ${ }^{22}$. Because there is not a 'gold standard' definition of dysphonia to compare with ${ }^{23}$, we classified a given definition as sensitive, when it was able to identify most of those who had the problem under investigation in the study population; and specific, when a definition allowed to identify most of those who were free from the problem under study in that population. As aimed in any epidemiological study, a good case definition would then identify everyone with the problem and exclude all without it, i.e., be sensitive and specific at the same time. 


\section{Results}

Using only 'voice disorder' as a key word, we found 3,186 citations in the Virtual Health Library, of which 333 were in Lilacs, 2,836 in Medline, 6 in ADOLEC, and 11 in BBO. Using 'voice disorder' and 'teachers' as descriptors, we found 31 citations in Scielo and 23 in Medline, of which only 15 fulfilled the inclusion criteria to discuss prevalence of vocal disorder in teachers.

The different definitions of voice disorder used in epidemiological studies and our comments are presented in Chart 1. Among the 15 selected epidemiological studies on voice disorder prevalence in teachers (Chart 1), only one study included the report of previous diagnosis of a laryngeal problem ${ }^{21}$ as one of the criteria.

Nine articles ${ }^{17-21,24-27}$ defined vocal dis- order based solely on the presence of vocal symptoms, but the list of symptoms varied slightly (Table 1 ). These nine studies were all regarded as very sensitive, since they would capture most of the people with any actual problem. However, specificity varied in relation to inclusion of number, frequency of symptoms and reference period. Regarding the frequency of symptoms - continuous ${ }^{28}$, frequent ${ }^{17}$ and occasional ${ }^{29}$ - the prevalence of voice disorders was lower for continuous symptoms. ${ }^{28}$ The reference period of symptoms was not specified in one article ${ }^{29}$ and three studies assessed lifelong prevalence ${ }^{18,25,30}$.

Hoarseness and vocal tiredness were mentioned in all studies that evaluated vocal symptoms. The other symptoms mentioned were, in decreasing order: pain when speaking, effort to speak, weak voice, aphonia and throat clearing (Table 1).

Table 1 - Frequency of vocal symptoms reported in 12 epidemiological studies on voice disorder in teachers that used symptoms in your definitions.

Tabela 1 - Freqüência de sintomas vocais relatados em 12 estudos epidemiológicos sobre disfonia em professores que usaram sintomas em suas definições

\begin{tabular}{|c|c|c|}
\hline Symptoms & Frequency & $\%$ \\
\hline Hoarseness $(17,18,19,20,21,24,25,26,27,28,32,33)$ & 12 & 100 \\
\hline Vocal tiredness $(17,18,19,20,21,24,25,26,27,28,32,33)$ & 12 & 100 \\
\hline $\begin{array}{l}\text { Pain when speaking or in the } \\
\text { throat }(18,19,24,26,28,32,33)\end{array}$ & 07 & 58 \\
\hline Effort to speak $(17,20,21,19,27,25)$ & 06 & 50 \\
\hline Weak voice $(17,18,19,20,21)$ & 06 & 50 \\
\hline Voice loss or Aphonia $(18,19,26,32,33)$ & 05 & 42 \\
\hline Throat clearing $(18,19,24,25,33)$ & 05 & 42 \\
\hline Voice breaks $(19,26,32,33)$ & 04 & 33 \\
\hline Throat soreness $(25,26,27)$ & 03 & 25 \\
\hline Dry throat $(25,27,32)$ & 03 & 25 \\
\hline Difficulty in being heard $(19,26,33)$ & 03 & 25 \\
\hline Difficulty in speaking in low voice $(17,20,21)$ & 03 & 25 \\
\hline Difficulty in speaking in loud voice $(17,20,21)$ & 03 & 25 \\
\hline Spasms in voice $(17,20,21)$ & 03 & 25 \\
\hline Hissing in voice $(17,20,21)$ & 03 & 25 \\
\hline Soreness $(32,24)$ & 02 & 17 \\
\hline Difficulty in projecting voice $(25,27)$ & 02 & 17 \\
\hline Loss of singing range ${ }^{(25,27)}$ & 02 & 17 \\
\hline Difficulty in singing $(25,27)$ & 02 & 17 \\
\hline Discomfort during phonation $(25,27)$ & 02 & 17 \\
\hline Monotone voice $(25,27)$ & 02 & 17 \\
\hline Coughing ${ }^{(19)}$ & 01 & 08 \\
\hline
\end{tabular}

\begin{tabular}{|c|c|c|}
\hline Symptoms & Frequency & $\%$ \\
\hline Sensation of foreign body ${ }^{(19)}$ & 01 & 08 \\
\hline Itching ${ }^{(18)}$ & 01 & 08 \\
\hline Pain or tension in the neck ${ }^{(32)}$ & 01 & 08 \\
\hline Breathlessness (27) & 01 & 08 \\
\hline Dryness ${ }^{(24)}$ & 01 & 08 \\
\hline Throat tightness (24) & 01 & 08 \\
\hline $\begin{array}{l}\text { Low voice or with diminished } \\
\text { intensity }{ }^{(29)}\end{array}$ & 01 & 08 \\
\hline Frequent changes in voice volume ${ }^{(28)}$ & 01 & 08 \\
\hline Voice variations during the day ${ }^{(38)}$ & 01 & 08 \\
\hline Difficulty in speaking softly ${ }^{(27)}$ & 01 & 08 \\
\hline Constriction (19) & 01 & 08 \\
\hline Loss of voice control ${ }^{(18)}$ & 01 & 08 \\
\hline Shortness of breath ${ }^{(18)}$ & 01 & 08 \\
\hline Voice alterations ${ }^{(24)}$ & 01 & 08 \\
\hline Deepening ${ }^{(29)}$ & 01 & 08 \\
\hline Increased intensity ${ }^{(25)}$ & 01 & 08 \\
\hline Difficulty in singing low/high pitches ${ }^{(18)}$ & 01 & 08 \\
\hline Voice tightness ${ }^{(18)}$ & 01 & 08 \\
\hline Sharp voice ${ }^{(29)}$ & 01 & 08 \\
\hline Choking ${ }^{(19)}$ & 01 & 08 \\
\hline Shaky voice ${ }^{(25)}$ & 01 & 08 \\
\hline Difficulty in speaking ${ }^{(25)}$ & 01 & 08 \\
\hline
\end{tabular}


Chart 1 - Different definitions of voice disorder used in epidemiological studies and comments on diagnosis criteria. Quadro 1 - As diferentes definições de disfonia usadas em estudos epidemiológicos e comentários sobre os critérios diagnósticos

\begin{tabular}{|c|c|c|}
\hline $\begin{array}{l}\text { Author, year and place } \\
\text { of publication }\end{array}$ & Definition & Comments \\
\hline $\begin{array}{l}\text { Urrutikoetxea et al. } \\
(1995), \text { Spain }^{(28)}\end{array}$ & $\begin{array}{l}\text { 1) Professional diagnosis of alterations in vocal folds and in voice quality. } \\
\text { 2) Report of hoarseness, vocal tiredness, frequent changes in voice volume } \\
\text { and pain when speaking: continuous, frequent and occasional. }\end{array}$ & $\begin{array}{l}\text { 1- Based on professional } \\
\text { evaluation. } \\
\text { 2- Based on individual's } \\
\text { subjectivity. }\end{array}$ \\
\hline $\begin{array}{l}\text { Smith et al. (1997). } \\
\text { Philadelphia/ USA. }{ }^{(17)}\end{array}$ & $\begin{array}{l}\text { Report of hoarseness, vocal tiredness, difficulty in speaking low, weak voice, } \\
\text { effort to speak, difficulty in speaking loud, spasms and hissing in the voice. } \\
\text { Frequency of symptoms not taken into account }\end{array}$ & $\begin{array}{l}\text { Based on individual's } \\
\text { subjectivity. }\end{array}$ \\
\hline $\begin{array}{l}\text { Bacha et al.(1999), } \\
\text { Campo Grande/MS/ } \\
\text { Brazil. }^{(32)}\end{array}$ & $\begin{array}{l}1 \text {-Report of vocal symptoms: hoarseness, voice breaks and voice loss. } \\
\text { 2- Report of sensorial symptoms: sore throat, pain in the nape, soreness in } \\
\text { the throat tiredness when speaking and dry throat. } \\
\text { 3- Report of frequent vocal and/or sensorial symptoms and of alterations in } \\
\text { the laryngeal and in voice quality. }\end{array}$ & $\begin{array}{l}\text { 1- Based on individual's } \\
\text { subjectivity. } \\
\text { 2- Based on individual's } \\
\text { subjectivity. } \\
\text { 3- Based on professional } \\
\text { evaluation. }\end{array}$ \\
\hline $\begin{array}{l}\text { Russell et al. (1998), } \\
\text { South Australia(31) }\end{array}$ & $\begin{array}{l}\text { Report of vocal problems in relation to the teacher's career. Frequency of } \\
\text { symptoms not taken into account. }\end{array}$ & $\begin{array}{l}\text { Based on individual's } \\
\text { subjectivity. }\end{array}$ \\
\hline $\begin{array}{l}\text { Smith et al. }(1998 a)^{20} \\
\text { and Smith et al. (1998b). } \\
\text { lowa/USA. }\end{array}$ & $\begin{array}{l}\text { Report of vocal symptoms associated to a teacher's work: hoarseness, vocal } \\
\text { tiredness, difficulty in speaking low, weak voice, effort to speak, difficulty in } \\
\text { speaking loud, spasms and hissing in the voice. Take into account duration } \\
\text { but not frequency of symptoms. }\end{array}$ & $\begin{array}{l}\text { Based on individual's } \\
\text { subjectivity. }\end{array}$ \\
\hline $\begin{array}{l}\text { Pordeus et al. (1999), } \\
\text { Fortaleza/CE/ Brazil(24) }\end{array}$ & $\begin{array}{l}\text { Report of vocal symptoms: dryness, throat clearing, soreness, hoarseness, } \\
\text { tightness sensation, pain, voice alterations and others. Different number of } \\
\text { symptoms and frequency. }\end{array}$ & $\begin{array}{l}\text { Based on individual's } \\
\text { subjectivity. }\end{array}$ \\
\hline $\begin{array}{l}\text { Sala et al. (2001). Hel- } \\
\text { sinki/Finland. }{ }^{(33)}\end{array}$ & $\begin{array}{l}\text { Report of two or more symptoms (throat clearing, vocal tiredness, } \\
\text { hoarseness, sore throat, voice breaks, difficulty in being heard, voice loss) at } \\
\text { least once a week plus alteration of vocal quality or laryngeal alteration. }\end{array}$ & $\begin{array}{l}\text { Based on individual's } \\
\text { subjectivity plus examination } \\
\text { by specialist. }\end{array}$ \\
\hline $\begin{array}{l}\text { Yiu (2002). Hong Kong/ } \\
\text { China }\end{array}$ & $\begin{array}{l}\text { Score based on frequency and presence of throat clearing, hoarseness, } \\
\text { shortness of breath, inability to sing sharp pitches, vocal tiredness or fatigue, } \\
\text { itchy throat, weak voice, sore throat, voice loss, voice tightness, inability to } \\
\text { sing deep pitches and loss of voice control. }\end{array}$ & $\begin{array}{l}\text { Based on individual's } \\
\text { subjectivity. }\end{array}$ \\
\hline $\begin{array}{l}\text { Fuess and Lorenz } \\
\text { (2003). Mogi das } \\
\text { Cruzes/SP/Brazil(25) }\end{array}$ & $\begin{array}{l}\text { 1- Report of voice disorder and vocal fatigue or pain when speaking. } \\
\text { 2- Report of diagnosis of laryngeal problem. } \\
\text { 3- Report of constant symptoms plus laryngeal alteration based on physical } \\
\text { examination. }\end{array}$ & $\begin{array}{l}\text { 1-Based on individual's } \\
\text { subjectivity. } \\
\text { 2-Based on previous } \\
\text { diagnosis. } \\
\text { 3-Based on professional } \\
\text { examination. }\end{array}$ \\
\hline $\begin{array}{l}\text { Simberg et al. (2004) } \\
\text { Turkey and Helsinki/ } \\
\text { Finland. }{ }^{(19)} \\
\end{array}$ & \begin{tabular}{|l|} 
Report of throat clearing or coughing, weak voice or hoarseness, strain or \\
tired voice, voice breaks, sensation of pain or foreign body in the throat, \\
difficulty in being heard and voice loss, according to frequency of symptoms.
\end{tabular} & $\begin{array}{l}\text { Based on individual's } \\
\text { subjectivity. }\end{array}$ \\
\hline $\begin{array}{l}\text { Roy et al (2004a). Utah } \\
\text { and lowa/USA. }{ }^{(25)}\end{array}$ & $\begin{array}{l}\text { Report of hoarseness, vocal fatigue, trouble in singing or speaking softly, loss } \\
\text { of singing range, discomfort during phonation, monotone voice, effort when } \\
\text { speaking, chronic sensation of dry or sore throat. Frequency not considered. }\end{array}$ & $\begin{array}{l}\text { Based on individual's } \\
\text { subjectivity. }\end{array}$ \\
\hline \begin{tabular}{|l|} 
Thibeault et al. (2004), \\
Utah and lowa/USA
\end{tabular} & $\begin{array}{l}\text { Report of vocal problem defined as 'voice that does not work' or 'does not } \\
\text { sound as usual' for at least } 4 \text { weeks. }\end{array}$ & $\begin{array}{l}\text { Based on individual's } \\
\text { subjectivity. }\end{array}$ \\
\hline $\begin{array}{l}\text { Roy et al. (2004b). lowa } \\
\text { and Utah/USA } \\
\text { (27) }\end{array}$ & $\begin{array}{l}\text { Report of any voice disorder in relation to its performance or production that } \\
\text { may interfere in communication. Vocal symptoms considered:hoarseness, } \\
\text { vocal fatigue, trouble speaking or singing, difficulty in projecting voice, } \\
\text { loss of singing range, discomfort when speaking, effort when speaking, } \\
\text { monotone voice, chronic dry throat, frequent throat clearing and shaky } \\
\text { voice. }\end{array}$ & $\begin{array}{l}\text { Based on individual's } \\
\text { subjectivity. }\end{array}$ \\
\hline $\begin{array}{l}\text { Simberg et al. (2005). } \\
\text { Turkey/Finland. }{ }^{(26)}\end{array}$ & $\begin{array}{l}\text { Report of voice tiredness, hoarseness, voice breaks, difficulty in being heard, } \\
\text { pain around larynx and aphonia, in the absence of cold. }\end{array}$ & $\begin{array}{l}\text { Based on individual's } \\
\text { subjectivity, but excludes } \\
\text { common cold. }\end{array}$ \\
\hline
\end{tabular}


Two studies ${ }^{30,31}$ did not present a list of vocal symptoms, using the term 'vocal problem' in a teacher's career to evaluate prevalence of vocal disorder. For this reason, we considered them as case definitions with low specificity.

Four studies based case definition on vocal or laryngeal evaluation by a qualified professional $^{28,29,32,33}$, being thus, more specific than the others. Three of them ${ }^{28,32,33}$ considered vocal qualities, laryngeal alteration and the report of audible perceptive and proprioceptive vocal symptoms. The study by Fuess \& Lorenz $(2003)^{29}$ is more specific than the others, since it includes that only those who reported constant problems had their larynx examined by a specialist.

Chart 2 presents the 15 studies and a summary of the prevalence of voice disorders among teachers. Twelve studies were carried out in developed countries and three in Brazil. Gender was only mentioned in five studies ${ }^{17,19,20,30,31}$.

The prevalence varied from $4 \%$ to $93.7 \%$, according to case definition, frequency of symptoms and period of reference. The prevalence of vocal disorders based on organic alterations was $20.84 \%^{28}$ and the one based on professional examination was $30.87 \%^{32}$. The prevalence based on current report of symptoms varied from $11 \%^{25}$ and $17 \%^{28}$. The report of occasional voice disorders was researched in two studies and, the prevalence varied from $57 \%{ }^{29}$ and $75 \% .^{28}$

\section{Discussion}

All studies included in this systematic review contribute to increase the knowledge on voice disorders in teachers and help to select the criteria to improve the definition of the condition in future observational studies. Despite the lack of a standard definition, studies included in this review show that the prevalence of voice disorders is high among teachers, reinforcing the importance of having a common definition to determine and compare its prevalence among different groups and to allow the investigation of possible workrelated risk factors for this condition.

As voice disorder is a complex phenomenon that is expressed in several ways and has different levels of severity, it would be interesting to have more than one standardized case definition, reflecting different stages and severity of the disorder. For instance, in earlier phases of functional voice disorder, symptoms are present, but it is rare to find any organic sign. When it becomes chronic, then both, symptoms and organic alterations in the vocal tract, tend to be present. The type, number and frequency of symptoms help to determine the severity of the problem.

Symptom reports seem appropriate, for instance, for screening purposes, and should include only current symptoms, which could be appreciated in relation to their effect on individuals' everyday lives, for instance. In prevalence studies, it is essential to adopt a clear definition, i.e., based on type, frequency, duration and number of symptoms. In studies aimed at assessing the severity of voice disorder, the inclusion of physical examination would allow a clearer description and classification of the problem.

The analysis of the studies also shows the use of different expressions to refer to the same symptom, as in the case of 'frequent changes in voice volume' or 'frequent voice variations'. Other symptoms are too generic and bring little information, such as 'discomfort during phonation'. Such diversity of vocal symptoms in the nomenclature increases the difficulties to interpret and compare different results on the prevalence of the disorder in teachers.

Studies such as the one by Scott et al. ${ }^{34}$, investigated vocal complaints of 133 dysphonic patients by means of an open-ended questionnaire inquiry and adopted the World Health Organization ${ }^{35}$ classification of impairments, disabilities and handicaps to categorize responses of patients who had been referred complaining of hoarseness. In his study, hoarseness, loss of voice, sore 


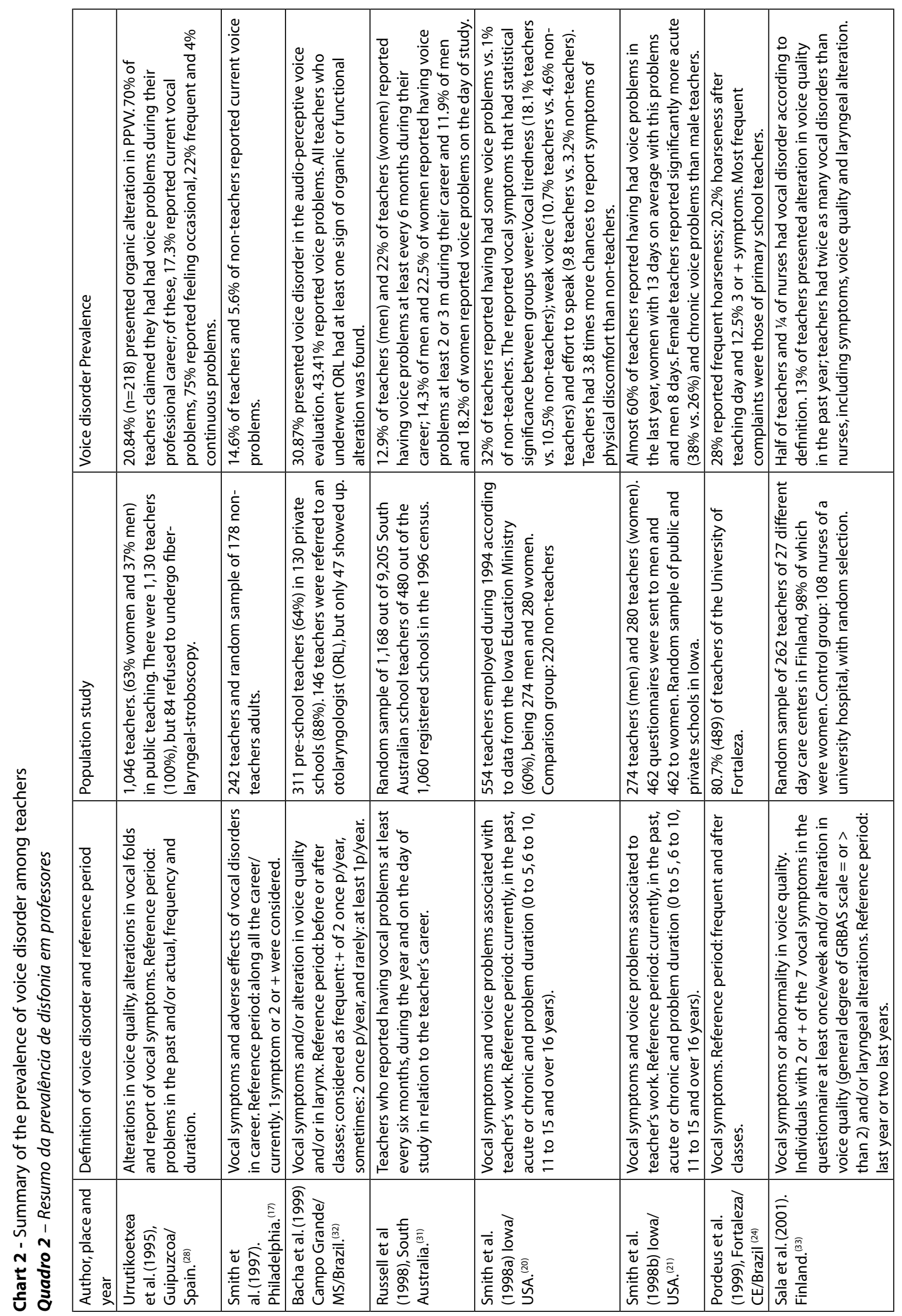




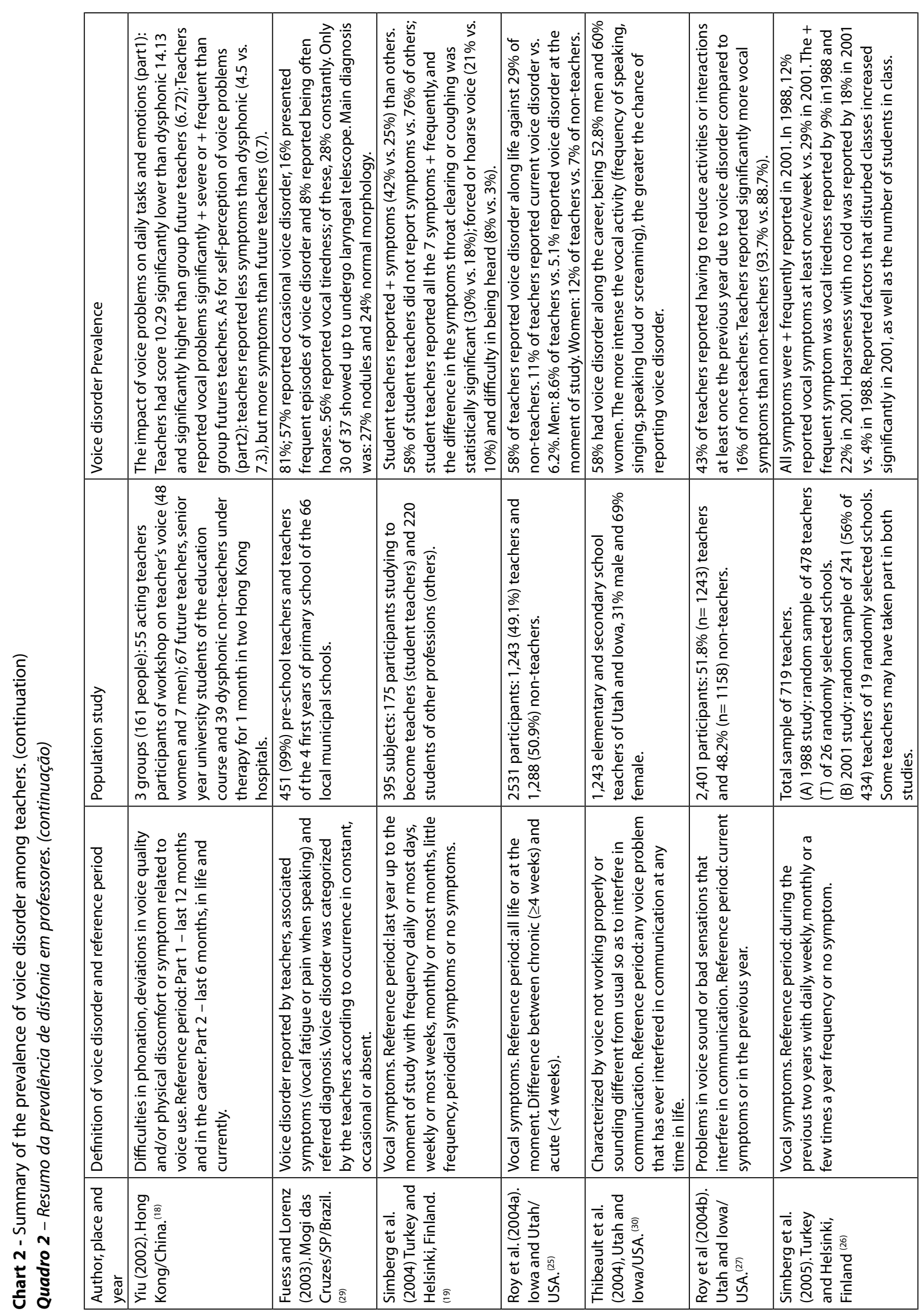


throat, cough/clear throat and dry throat are the most frequent impairments; problems singing, inability to talk/be heard and difficulty to be understood were the most common disabilities; employment related difficulties, frustration, low socialization and loss of confidence were the most common handicaps. This example shows that, more than identifying and measuring the occurrence of voice disorders, it would be interesting to use the new WHO's International Functionality, Incapability and Health Classification $^{36}$, which is even more comprehensive than the previous one, to estimate the whole impact of the disorder.

Gender was not mentioned by ten out of 15 studies $^{17,18,21-29,33}$. However, voice disorders are not evenly distributed among men and women. They are more common among women ${ }^{20,31}$. The higher frequency of voice disorders among women seems to be explained by the smaller size of their larynx and their lower vocal power. In the case of female teachers, they need to raise their voice intensity because their fundamental frequency is very close to the children's (sol 2 and re 3 versus si 2 and mi 3) ${ }^{37}$. Vilkman ${ }^{1}$ also noticed that a male voice produces $50 \%$ less vibrations in total than a female voice. As a result of such differences, it is essential that the prevalence of voice disorders be presented separately for men and women.

In relation to sensitivity and specificity, it is interesting to note how different case definitions will impact on the prevalence of voice disorders. In the study in Porto Alegre,
$\operatorname{Brazil}^{40}$, voice disorder is defined as 'the presence of vocal alterations acoustically perceptible by three speech doctors' and 'self-perception of vocal alterations or symptoms'. We regard the first case definition as more specific than sensitive, given speech doctors are well trained to detect people with no vocal alteration and are less likely to miss a real case. The second definition, on the other hand, is more sensitive than specific, because it is based solely on the individual's self-perception of vocal alteration. The use of these different definitions directly affected voice disorder prevalence, which was lower (46\%) using 'acoustically perceptible voice disorder' and, much greater $(80 \%)$, using frequent or occasional self-perceived vocal alteration.

\section{Conclusion}

Despite the complexity and inherent difficulties in defining voice problems, it is important to standardize case definitions of voice disorders that can be used in observational studies. This is an important step that will allow better understanding of the problem. Moreover, it will be possible to compare the results of studies from different populations and along time in the same population with greater certainty. Standardization of criteria for case definition is also essential to assess the impact of interventions aiming at preventing or reducing the occurrence or severity of voice disorder in risk groups.

\section{References}

1. Vilkman E. Voice problems at work: a challenge for occupational safety and health arrangement. Folia Phoniat et Logop 2000;52:120-125.

2. Gonçalves GBB. Uso profissional da voz em sala de aula e organização do trabalho docente. Dissertação

(dissertação de mestrado). Belo Horizonte: Faculdade de Educação da Universidade Federal de Minas Gerais; 2003.

3. Silvany-Neto AM, Araújo TM, Alves RL, Azi GR, Dutra FRD, Kavalkievicz C., Reis EJFB. Condições de trabalho e saúde de professores da rede particular de ensino de Salvador, Bahia. Revista Baiana de Saúde Pública. Jan./ dez. 2000; 24: n.1/2; 42-56.
4. Martins MIM, Taú MC, Unzueta VMP, MomensohnSantos TM. A interferência do ruído no reconhecimento da fala: análise do ambiente e da voz do professor. XX Encontro da Sociedade Brasileira de Acústica - Sobrac, II Simpósio Brasileiro de Metrologia em Acústica e Vibrações - Sibrama: Rio de Janeiro. Out.2002. p. 21-24.

5. Melnyk P, Jamardo B, Cacace M, Pardo H, Pino AA, Tomasetti A Cortizas M.M.A, Hurtado DE, Braier MR, Verretilne G. Considerations about teachers'voice disorders. International Congress Series 1240. 2003: 12936. 
6. Delcor NS, Araújo TM, Reis EJFB, Porto LA, Carvalho FM, Silva MO, Barbalho L, Andrade MA. Condições de trabalho e saúde dos professores da rede particular de ensino de Vitória da Conquista, Bahia, Brasil. Cad Saúde Pública 2004; 20(1):187-96.

7. Yiura LH, Miranda SM, Margall SAC. Comparação da produção gráfica de crianças a partir da emissão vocal de professores com e sem alterações de voz. In: Coleção Sociedade Brasileira de Fonoaudiologia. Atualização em Voz, Linguagem, Audição e Motricidade Oral. São Paulo: Frôntis Editorial; 1999: 95-110.

8. Rogerson J; Dodd B. Is there an effect of dysphonic teachers' voices on children's processing of spoken language? J Voice 2005; 19(1): 47-60.

9. Vilkman E. Ocupational safety and health aspects of voice and speech professions. Folia Phoniatrica et Logopaedica. 2004; 56:220-53.

10. Behlau M. Dragone MLS; Nagano L. A voz que ensina: $o$ professor e a comunicação oral em sala de aula. Rio de Janeiro: Revinter; 2004.

11. Aronson, AE. Clinical voice disorders. 3 ed., INC. New York: Thieme Medical Publishers; 1990. p. 3-11.

12. Spiegel JR, Sataloff RT, Emerich KA. The young adult voice. J Voice 1997; 11(2):138-43.

13. Gordis, L. Epidemiology. $2^{\text {a }}$ ed. Filadélfia: W.B. Saunders Company; 2000.

14. Behlau M, Azevedo R, Pontes P. Conceito de Voz Normal e Classificação das Disfonias. In: Behlau M (ed.), Voz: $O$ Livro do Especialista. $1^{\text {a }}$ ed., Rio de Janeiro: Revinter; 2001b.

15. The American Heritage ${ }^{\circledR}$ Stedman’s Medical Dictionary. Retrieved July 04, 2007, from Dictionary.com website: http://dictionary.reference.com/browse/dysphonia.

16. Pinho SMP. Manual de higiene vocal para profissionais da voz. Revista Pró-Fono; 2003.

17. Smith E, Gray SD, Dove H, Kirchner L, Heras H. Frequency and effects of teachers voice problems. $J$ Voice 1997; 11(1): 81-7.

18. Yiu EM. Impact and prevention of voice problems in the teaching profession: embracing the consumers' view. $J$ Voice 2002; 16(2): 215-28.

19. Simberg S., Sala, E \& Rönnemaa, A. A comparison of the prevalence of vocal symptoms among teacher students and other university students. J Voice 2004; 18(3): 363-8.

20. Smith E, Lemke J, Taylor M, Kircher HL, Hoffman H. Frequency of voice problems among teachers and other occupations. J Voice 1998(a); 12(4): 480-8.

21. Smith E, Kirchner LH, Taylor M, Hoffman H, Lemke JH. Voice problems among teachers: differences by gender and teaching characteristics. J Voice 1998(b);12(3): 32834 .
22. Rouquayrol MZ. Epidemiologia \& Saúde. Rio de Janeiro: Medsi: Editora Médica e Científica Ltda.; 1994.

23. Gordis, L. Epidemiology. $2^{\text {a }}$ ed. Filadélfia: W.B. Saunders Company 2000.

24. Pordeus AMJ, Palmeira CT, Pinto VCV. Inquérito de prevalência de problemas da voz em teachers da universidade de Fortaleza. Revista Pró-Fono 1996; 8(2): 25-30.

25. Roy N, Merril RM, Thibeault S, Parsa RA, Gray SD, Smith EM. Prevalence of voice disorders in teachers and the general population. J Speech, Language, and Hear Res 2004(a); 47: 281-93.

26. Simberg S, Sala E, Vehmas K, Laine A. Changes in the prevalence of vocal symptoms among teachers during a twelve-year period. J Voice 2005; 19(1): 95-102.

27. Roy N, Merril RM, Thibeault S, Gray SD, Smith EM. Voice disorders in teachers and the general population: effects on work performance, attendance, and future career choices. J Speech, Language, and Hear Res 2004(b); 47: 542-51.

28. Urrutikoetxea A, Ispizua A, Matellanes F. Pathologie vocale chez les professeurs: une étude vidéo-laryngostroboscopique de 1.046 professeurs. Rev Laryngol Oto Rhino. 1995; 116(4): 255-62.

29. Fuess VLR, Lorenz MC. Disfonia em professores do ensino municipal: prevalência e fatores de risco. Revista Brasileira de Otorrinolaringologia. São Paulo: 2003; 69: 807-12.

30. Thibeault SL, Merril RM, Roy N, Gray SD, Smith EM. Occupational risk factors associated with voice disorders among teachers. Ann Epidemiol 2004; 14: 786-92.

31. Russell A, Oates J, Greenwood K M. Prevalence of voice problems in teachers. J Voice Philadelphia 1998; 12(4): 467-79.

32. Bacha SMC, Camargo AFFP, Brasil MLR et al. Incidência de disfonia em professores de pré-escola do ensino regular da rede particular de Campo Grande/MS. Carapicuíba: Revista Pró-Fono. 1999; 11(2): 8-14.

33. Sala E, Laine A, Simberg S, Pentti J, Suonpää J. The prevalence of voice disorders among day care center teachers compared with nurses: a questionnaire and clinical study. J Voice 2001;15(3): 413-23.

34. Scott S, Robinson K, Wilson JA, Mackenzie K. Patientreported problems associated with voice disorder. Clin Otolaryngology 1997; 22: 37-40.

35. Organização Mundial da Saúde (OMS). Classificação internacional de doenças. São Paulo: Centro da OMS para Classificação de Doenças em Português; revisão 1975.

36. Organização Mundial da Saúde. Classificação internacional de funcionalidade, incapacidade e saúde. São Paulo: Editora da Universidade de São Paulo; 2003. 
37. Calas M, Verhulst J, Lecoq M, Dalleas B, Seilhean M. La pathologie vocale chez l' enseignant. Revue de Laryngologie 1989;110(4): 397-406.

38. Krischke, S. Weigelt, S., Ulrich, H., Köllner, V., Klotz, M., Eysholdt, U. \& Rosanowski, F. Quality of life in dysphonic patients. JVoice 2005;19 (1):132-7.

39. Ma, Estella P_M \& Yiu, Edwin M-L. Voice activity and participation profile: Assessing the impact of voice disorders on daily activities. J of Speech, Language, and Hear Res 2001; 44; 511-36.
40. Scalco MAG, Pimentel RM, Pilz W. A saúde vocal do professor: levantamento junto a escolas particulares de Porto Alegre, Revista Pró-Fono 1996; 8(2): 25-30.

Recebido em: 28/08/06 Versão final reapresentada em: 13/07/07 Aprovado em: 10/09/07 